\title{
NEPRUŽANJE ZDRAVSTVENE SKRBI KAO POVREDA ČLANKA 3. EUROPSKE KONVENCIJE $S$ POSEBNIM OSVRTOM NA PRAKSU SUDA U PREDMETIMA IZVAN KONTEKSTA ZADRŽAVANJA***
}

Sažetak: $\quad$ Europska konvencija za zaštitu ljudskih prava kao temeljni instrument Vijeća Europe za zaštitu građanskih i političkih prava ne jamči pravo na zdravstvenu zaštitu. Međutim, Europski sud za ljudska prava široko tumači Konvencijska prava te je unutar konteksta čl. 2., 3. i 8. Konvencije dao određene naznake da bi se mogao početi baviti i pitanjem zdravstvene zaštite. Bez ulaženja u detalje svih spomenutih članaka, u ovom radu bit će analizirani predmeti u kojima se Sud bavio pitanjem povrede čl. 3. zbog nepružanja zdravstvene skrbi i to izvan konteksta zadržavanja. Naime, unutar konteksta zadržavanja postoji jasna obveza državama na pružanje zdravstvene skrbi koju je Sud utvrdio djelomično se oslanjajući i na izvješća i Odbora za sprječavanje mučenja, neljudskog $i$ ponižavajućeg ponašanja. Ono što smatramo značajnim istaknuti jest praksa Suda u odnosu na pružanje zdravstvene skrbi izvan konteksta zadržavanja, s obzirom na socijalni karakter prava na zdravstvenu zaštitu koji izlazi iz okvira građansko-političkog karaktera Konvencije.

Ključne riječi: Europska konvencija za zaštitu ljudskih prava i temeljnih sloboda; čl. 3., zdravstvena skrb izvan konteksta zadržavanja

\footnotetext{
Dr. sc. Maša Marochini Zrinski, docentica Pravnog fakulteta Sveučilišta u Rijeci, Hahlić 6, 51000 Rijeka. E-adresa: mmarochini@ pravri.hr, ORCID: https://orcid.org/0000-0002-8441-2277.

** Karin Derenčin Vukušić, mag. iur. E-adresa: karin.vukusic@gmail.com. ORCID: https://orcid.org/0000-0002-7465-8310.

*** Ovaj rad je nastao u koautorstvu nastavno na diplomski rad Karin Derenčin Vukušić Nepružanje medicinske skrbi kao povreda članka 3. Europske konvencije za zaštitu ljudskih prava i temeljnih sloboda unutar i izvan konteksta zadržavanja napisan pod mentorstvom doc. dr. sc. Maše Marochini Zrinski te obranjen na Pravnom fakultetu Sveučilišta u Rijeci u srpnju 2020.
} 


\section{UVOD}

Na razini Vijeća Europe, pravo na zdravstvenu zaštitu tradicionalno je socijalno-ekonomsko sadržano u Europskoj socijalnoj povelji (dalje u tekstu: Povelja) ${ }^{1}$ te potpuno isključeno iz teksta Europske konvencije za zaštitu ljudskih prava i temeljnih sloboda (dalje u tekstu: Konvencija, Europska konvencija). ${ }^{2}$ Međutim, pitanje pružanja zdravstvene zaštite nije potpuno isključeno iz konvencijske zaštite već je pokrenuto pred Europskim sudom za ljudska prava (dalje u tekstu: Sud, Europski sud), i to uglavnom u vezi s čl. 2. (pravo na život), čl. 3. (zabrana mučenja, nečovječnog i ponižavajućeg postupanja i kažnjavanja) i čl. 8. (pravo na poštovanje privatnog i obiteljskog života, doma i dopisivanja). Do pokretanja pitanja pružanja zdravstvene zaštite u okviru Konvencije dolazi zahvaljujući primjeni 'integriranog pristupa' Suda pri tumačenju prava iz Konvencije. Ovaj je pristup zasnovan na nedjeljivosti svih ljudskih prava i „prepoznaje da, s jedne strane, uživanje građanskih i političkih prava zahtijeva poštivanje i promicanje socijalnih prava, a s druge strane da socijalna prava nisu podređena građanskim i političkim pravima." ${ }^{3}$ Može se reći kako integrirani pristup ima prednost s obzirom na to da otvara vrata kreativnim mogućnostima parničenja socijalnih prava i rekonceptualizacije kontura građanskih i političkih prava. ${ }^{4} \mathrm{~S}$ druge strane, Europski sud je oprezan pri tumačenju Konvencije na način da se njome jamče (ekonomska i socijalna) prava koja nisu zajamčena Konvencijom, s obzirom na to da bi takvim tumačenjem izašao iz okvira interpretatora Konvencije i ušao u (zabranjenu) sferu stvaranja prava. ${ }^{5}$

Iako pojedinci koji se pozivaju na povredu konvencijskih prava uskraćivanjem zdravstvene skrbi načelno to čine pozivajući se na čl. 2. i 8., dok primat u predmetima uskrate zdravstvene skrbi i povrede čl. 3. imaju predmeti unutar konteksta zadržavanja, oni neće biti predmet ovog rada. Nije izvjesno da će se pojedinci kojima je uskraćena zdravstvena skrb pozivati na povredu čl. 3.: pozivat će se ili na povredu prava na privatni život ili, u slučaju smrtnog ishoda, prava na život. Upravo zato smatramo zanimljivim prikazati i analizirati predmete u kojima su se pojedinci ipak pozvali na povredu zabrane mučenja, nečovječnog i ponižavajućeg postupanja te kažnjavanja zbog nepružanja adekvatne zdravstvene skrbi.

Slijedom napisanog, u ovom radu prikazat će se predmeti u kojima se pojedinci pred Sudom pozivaju na povredu čl. 3. Konvencije zbog nepružanja zdravstvene skrbi izvan konteksta zadržavanja razmatrajući koliko daleko je išao Sud u tumačenju Konvencije u ovim predmeti-

1 Zakon o potvrđivanju Europske socijalne povelje, Dodatnog protokola Europskoj socijalnoj povelji, Protokola o izmjenama Europske socijalne povelje i Dodatnog protokola Europskoj socijalnoj povelji kojim se uspostavlja sustav kolektivnih žalbi, (NNMU 15/2002).

2 (Europska) Konvencija za zaštitu ljudskih prava i temeljnih sloboda, pročišćeni tekst, (NN-MU 18/1997, 6/1999, 14/2002, 13/2003, 9/2005, 1/2006, 2/2010).

3 Bernardette Rainey, Elizabeth Wicks and Clare Ovey, The European Convention on Human Rights (5th edn, OUP 2017 ) 75.

4 Alicia Ely Yamin, 'The Future in the Mirror: Incorporating Strategies for the Defense and Promotion of Economic, Social and Cultural Rights into the Mainstream Human Rights Agenda' (2007) 27(4) HRQ 1200, 1219.

5 Za više o tumačenju Konvencije na način da se takvim tumačenjem ulazi u sferu socijalno-ekonomskih prava vidi Maša Marochini, Socio-Economic Dimension of the European Convention on Human Rights (Pravni fakultet u Rijeci 2013); Ida Elizabeth Koch, Human Rights As Indivisible Rights: The Protection of Socio-Economic Demands Under the European Convention On Human Rights (Brill-Nijhoff 2009); Eva Brems, 'Indirect Protection of Social Rights by the European Court of Human Rights' u Daphne Barak-Erez and Aeyal Gross (eds), Exploring Social Rights Between Theory and Practice (Hart Publishing, Oxford, 2007). 
ma te je li uspostavio određene standarde odlučivanja. ${ }^{6}$ Naime, Europski sud je razvio vlastita načela tumačenja koja primjenjuje donoseći presude i kojima se služi kako bi dodatno razvio svoju praksu u brojnim predmetima, uključujući i one koji se odnose na pružanje zdravstvene skrbi izvan konteksta zadržavanja. Svakako je važno spomenuti načela živućeg instrumenta i učinkovitosti zahvaljujući kojima je Sudu omogućeno široko tumačenje čl. 3., a o kojima će biti više govora u nastavku.

\section{2. ČLANAK 3. KONVENCIJE I NJEGOVO TUMAČENJE}

Članak 3. Konvencije glasi: „Nitko se ne smije podvrgnuti mučenju ni nečovječnom ili ponižavajućem postupanju ili kažnjavanju“ te je usmjeren na zaštitu ljudskog dostojanstva i osobnog integriteta. Člankom 15. predviđena je mogućnost derogiranja određenih konvencijskih prava u vrijeme izvanrednog stanja, međutim čl. 3. ne smije se derogirati. Naime, prava koja se štite čl. 3. smatraju se apsolutno nederogabilnim pravima, što znači da ne postoje razlozi na koje bi se ugovorna stranka Konvencije mogla pozvati u slučaju ograničavanja vršenja prava. ${ }^{7}$ U predmetu Irska protiv Ujedinjene Kraljevine Sud je razlikovao i definirao tri pojma, odnosno tri stupnja težine u postupanju ili kažnjavanju: mučenje, nečovječno postupanje ili kažnjavanje te ponižavajuće postupanje. Sukladno tome, mučenje predstavlja namjerno nečovječno postupanje koje uzrokuje vrlo ozbiljne i teške patnje; nečovječnim postupanjem ili kažnjavanjem smatra se nanošenje intenzivne tjelesne i duhovne patnje, dok se ponižavajuće postupanje definira kao zlostavljanje s ciljem da se u žrtvama pobudi osjećaj straha, tjeskobe i manje vrijednosti, koje je u stanju poniziti ih i vjerojatno slomiti njihov tjelesni ili moralni otpor. ${ }^{8}$ Sud će pri utvrđivanju je li došlo do navedenih povreda postaviti dva pitanja: prvo, postoji li minimalni stupanj okrutnosti u postupanju na koje se podnositelj poziva i drugo, ako je zadovoljeno uvjetu minimalnog stupnja okrutnosti, predstavlja li takvo postupanje mučenje, nečovječno postupanje ili kažnjavanje, odnosno ponižavajuće postupanje. Minimalni stupanj okrutnosti Sud će ispitivati razmatrajući okolnosti svakog pojedinog slučaja, uzimajući u obzir dob žrtve, njezino zdravstveno stanje, kao i trajanje samog postupanja. ${ }^{9}$

Govoreći o nečovječnom ili ponižavajućem postupanju ili kažnjavanju, važno je napomenuti da razlikujemo takvo postupanje, odnosno kažnjavanje, unutar i izvan konteksta zadržavanja. ${ }^{10}$ Nadalje, u čl. 3. također može doći do povrede i materijalnog i postupovnog aspekta, kao i do povrede negativne i pozitivne obveze države. Dvije su pozitivne obveze države sadržane u čl. 3. Prva je materijalna obveza države da spriječi zlostavljanje, a druga je postupovna obveza

6 Za detaljnu analizu prava na zdravstvenu zaštitu unutar Vijeća Europe vidi Maša Marochini,'Council of Europe and the Right to Healthcare- Is the European Convention on Human Rights appropriate Instrument for Protecting the Right to Healthcare?' (2013) 34(2) Zbornik Pravnog fakulteta Sveučilišta u Rijeci, 729, dok za prikaz zaštite koju pruža čl. 3. unutar konteksta zadržavanja vidi Maša Marochini, ‘The Ill-treatment of Prisoners in Europe: a Disease Diagnosed but not Cured?' (2009) 30(2) Zbornik Pravnog fakulteta Sveučilišta u Rijeci, 1108.

7 Jasna Omejec, Konvencija za zaštitu ljudskih prava i temeljnih sloboda: Strasbourški acquis (Novi informator 2014 ) 843.

8 (1979-80) 2 EHRR 25 (167).

9 Aisling Reidy, The Prohibition of Torture: a guide to the Implementation of Article 3 of the European Convention on Human Rights (Council of Europe 2003) <https://www.refworld.org/docid/49f1829b2.html> pristupljeno 13. srpnja 2021. 
države istražiti navodne slučajeve zlostavljanja i primijeniti odgovarajuće sankcije. Čak i kada Sud ne može utvrditi je li došlo do materijalne povrede čl. 3. Konvencije (npr. nije moguće utvrditi činjenično stanje), može ispitivati je li država povrijedila postupovni aspekt čl. $3 .{ }^{11}$ Upravo korištenjem načela učinkovitosti, odnosno nametanjem pozitivnih obveza državama ugovornicama, Sud daje odredbama Konvencije „punu težinu i učinak koji se podudaraju s jezikom koji se koristi i s ostatkom teksta i na takav način da se svakom njegovom dijelu može dati značenje." ${ }^{2}$ Srž je ovog načela da države ne mogu postupati u skladu s Konvencijom jednostavnom zabranom ponašanja koje je u suprotnosti s Konvencijom, već moraju poduzeti pozitivne mjere radi zaštite prava.

Također, govoreći o tumačenju Konvencije, ${ }^{13}$ bitno je napomenuti kako, prema stajalištu Suda, Konvencija predstavlja živući instrument te je interpretacija njezina teksta evolutivna, ${ }^{14}$ iz čega proizlazi kako bi određeno ponašanje koje danas predstavlja mučenje, u prošlosti vjerojatno bilo okarakterizirano kao nečovječno postupanje. ${ }^{15}$

Govoreći o čl. 3., važno je spomenuti i Europsku konvenciju o sprječavanju mučenja i neljudskog ili ponižavajućeg postupanja ili kažnjavanja, kao svojevrsno pojačanje čl. 3. Tijelo zaduženo za nadzor nad provedbom spomenute Konvencije jest Europski odbor za sprječavanje mučenja i neljudskog ili ponižavajućeg postupanja ili kažnjavanja (dalje u tekstu: CPT) koji nije sudsko tijelo već donosi isključivo neobvezujuća izvješća. S obzirom na to da je djelovanje CPT-a usmjereno na ustanove u kojima borave osobe lišene slobode, u predmetnom radu nećemo se detaljnije baviti spomenutom Konvencijom niti CPT-om. ${ }^{16}$

$11 \quad$ Ibid 47.

12 Donald McRae, 'Approaches to the Interpretation of Treaties: The European Court of Human Rights and the WTO Appellate Body' u Stephan Breintenmoser and others (eds), Human Rights, Democracy and the Rule of Law: Liber amicorum Luzius Wildhaber (Nomos 2007) 1411-1412.

13 Iz perspektive međunarodnog javnog prava, s obzirom na to da je Konvencija multilateralni međunarodni ugovor, njezino tumačenje regulira Bečka konvencija o pravu međunarodnih ugovora (dalje u tekstu: Bečka konvencija), NN-MU 16/1993, koja je ujedno i dio međunarodnog običajnog prava. Opća pravila tumačenja kodificirana su u Bečkoj konvenciji. Relevantne odredbe za tumačenje predstavljaju čl. 31., 32. i 33. Sud se rijetko izravno poziva na samu Bečku konvenciju, iako bismo mogli reći da se brojna načela tumačenja koja koristi Sud mogu izvesti iz teleološke metode kako je utvrđeno čl. 31. Bečke konvencije, prije svega načelo evolutivnog tumačenja kao i načelo učinkovitosti.

14 Europski sud sagledava Konvenciju kao „instrument koji živi” ili „živući instrument” (engl. living instrument; franc. un instrument vivant) za zaštitu ljudskih prava i temeljnih sloboda. On tumači konvencijska prava i primjenjuje Konvenciju sukladno uvjetima u državama članicama koji postoje u relevantno vrijeme kad je nastao događaj zbog kojeg je pokrenut postupak, ali samo do trenutka dok ne utvrdi da bi takvo tumačenje Konvencije bilo suprotno današnjem stupnju razvitka europskog društva. $\mathrm{U}$ takvim slučajevima, navodne povrede konvencijskih prava ispituje sukladno uvjetima u državama članicama koji postoje $u$ vrijeme donošenja presude. Tako je u predmetu Tyrer v The United Kingdom ((1978-80) 2 EHRR 1) Sud utvrdio da sudska presuda kojom se izriče tjelesna kazna maloljetniku znači povredu čl. 3. Konvencije, pri čemu je u obzir uzeo standarde u europskom društvu u vrijeme donošenja presude. U toj je presudi Europski sud istaknuo da je Konvencija živi instrument koji se mora tumačiti u svjetlu današnjih (present-day) uvjeta te da u predmetu koji je pred njim, ne može drugo nego biti pod utjecajem razvitka i općeprihvaćenih standarda u kaznenoj politici članica Vijeća Europe u tom području. Za više, vidi Hanneke Senden, 'Interpretation of fundamental rights in a multilevel legal system: an analysis of the European Court of Human Rights and the Court of Justice of the European Union', (Doctoral Thesis, Leiden University 2011); Adam Wisniewski, The European Court of Human Rights, Between judicial activism and passivism (Gdansk University Press 2016); Steven Greer, The European Convention on Human Rights. Achievements, Problems and Prospects (CUP 2006); Maša Marochini, 'The interpretation of the European Convention on Human Rights' (2014) 51(1) Zbornik radova Pravnog fakulteta u Splitu 63.

15 Selmouni v France (2000) 29 EHRR 403 „... Izvjesne radnje koje su se u prošlosti klasificirale kao 'nečovječno ili ponižavajuće postupanje' suprotno od 'mučenja' mogu se u budućnosti kvalificirati drugačije ... U području zaštite ljudskih prava i temeljnih sloboda postavljaju se sve viši standardi što nužno zahtijeva veću strogost i odlučnost u procjeni povreda temeljnih vrijednosti demokratskih društava" [101].

16 Za više o Konvenciji i CPT-u vidi About the CPT (Council of Europe, 2021) 〈https://www.coe.int/en/web/cpt/about-the-cpt> pristupljeno 10. rujna 2020. 


\section{OPĆENITO O PRAVU NA ZDRAVSTVENU ZAŠTITU}

Andrija Štampar pojam zdravlja definirao je kao stanje potpunog fizičkog, psihičkog i socijalnog blagostanja, a ne samo odsutnost bolesti i iznemoglosti. Ova definicija prihvaćena je od strane Svjetske zdravstvene organizacije te se kao takva nalazi u preambuli njezina Ustava iz 1946. godine. ${ }^{17}$

Pravo na zdravstvenu zaštitu socijalno je pravo osigurano mnogobrojnim dokumentima. Primjerice, Opća deklaracija o ljudskim pravima propisuje sljedeće: „Svatko ima pravo na životni standard koji odgovara zdravlju i dobrobiti njega samoga i njegove obitelji, uključujući prehranu, odjeću, stanovanje, liječničku njegu i potrebne socijalne usluge, kao i pravo na sigurnost u slučaju nezaposlenosti, bolesti, nesposobnosti, udovištva, starosti ili nekog drugog nedostatka sredstava za život u uvjetima koji su izvan njegove kontrole.“18 Člankom 35 . Povelje Europske unije o temeljnim pravima propisano je: „Svatko ima pravo na pristup preventivnoj zdravstvenoj zaštiti i pravo na liječenje pod uvjetima utvrđenima nacionalnim zakonodavstvima i praksom. Pri utvrđivanju i provedbi svih politika i aktivnosti Unije osigurava se visok stupanj zaštite zdravlja ljudi." ${ }^{19}$ Zdravstvena zaštita osigurana je i nacionalnim zakonodavstvima pa tako i Ustavom Republike Hrvatske: „,Svakom se jamči pravo na zdravstvenu zaštitu u skladu sa zakonom."20

Pravo na zdravstvenu zaštitu jamči i Europska socijalna povelja u čl. 11. koji glasi: „Radi osiguranja učinkovitog ostvarivanja prava na zdravstvenu zaštitu, ugovorne stranke se obvezuju poduzeti, bilo izravno bilo u suradnji s javnim ili privatnim organizacijama, odgovarajuće mjere prvenstveno usmjerene na to da: 1. uklone, koliko je to moguće, uzroke slaboga zdravlja; 2. osiguraju službe savjetovanja i obrazovanja radi poboljšanja zdravlja i razvoja osobne odgovornosti za zdravlje; 3. spriječe, koliko je to moguće, epidemijske, endemijske i druge bolesti." Povelja, uz Europsku konvenciju, predstavlja ključan instrument Vijeća Europe za zaštitu ljudskih prava. Dok Konvencija predstavlja temeljni instrument za zaštitu građanskih i političkih prava, Povelja predstavlja svojevrsni komplement Konvenciji u zaštiti ekonomskih i socijalnih prava. Potpisana je u Torinu 1961. godine, a stupila je na snagu 1964. godine te je u svom izvornom tekstu sadržavala 19 socijalnih i ekonomskih prava. Dodatnim protokolom iz 1988. godine dodana su još 4 prava, a 1996. usvojen je izmijenjen tekst Povelje koji sadrži 31 pravo. Poveljom je osnovan Europski odbor za socijalna prava čija je zadaća nadzor provedbe Povelje i donošenje zaključaka o usklađenosti nacionalnih zakonodavstava i prakse s odredbama Povelje. Za razliku od Suda, Odbor za socijalna prava nema sudske ovlasti, već donosi preporuke i zaključke. ${ }^{21}$

17 Ustav Svjetske zdravstvene organizacije, 2006 <https://www.who.int/governance/eb/ who_constitution_en.pdf.> pristupljeno 13. srpnja 2021.

18 Odluka o objavi Opće deklaracije o ljudskim pravima, (NN-MU 12/2009) čl. 25., st. 1.

19 Povelja Europske unije o temeljnim pravima (2012) OJ C326/391, čl. 35.

20 Ustav Republike Hrvatske, pročišćeni tekst, (NN 56/1990, 135/1997, 8/1998, 113/2000, 124/2000, 28/2001, 41/2001, 55/2001, 76/2010, 85/2010, 5/2014) čl. 59.

21 Za više o Europskoj socijalnoj povelji i radu Europskog odbora za socijalna prava vidi European Social Charter (Council of Europe, 2021) <https://www.coe.int/en/web/european-social-charter/home> pristupljeno 13 srpnja 2021; David Harris, The European Social Charter, The Protection of Economic and Social Rights in Europe (2nd edn, Brill-Nijhoff 2011); Maša Marochini Zrinski, 'Primjena Europske socijalne povelje s posebnim naglaskom na Republiku Hrvatsku' (2014) 14(11) Hrvatska pravna revija 42; 
Iz navedenog je vidljivo kako, unatoč teorijskom stajalištu o svim ljudskim pravima kao nedjeljivim, međuovisnim i povezanim pravima, ${ }^{22}$ kao i proklamacijama o njihovoj nedjeljivosti, ${ }^{23}$ i dalje postoji, posebice u okviru Vijeća Europe, jasna distinkcija između građanskih i političkih prava s jedne strane te ekonomskih i socijalnih s druge. Navedena distinkcija rezultat je prevladavajućeg stajališta iz vremena donošenja Konvencije kako su građanska i politička prava 'prve generacije', dok su ekonomska i socijalna prava 'druge generacije'. ${ }^{24}$ Iako je danas takvo stajalište napušteno u teoriji ${ }^{25} \mathrm{u}$ okviru Vijeća Europe nema vidljive namjere za usvajanjem integralnog pristupa u zaštiti ljudskih prava. S obzirom na napisano opravdani je strah kako bi tumačenjem Konvencije od strane Suda na način da donosi presude iz domene ekonomskih i socijalnih prava, Sud izašao iz okvira tumačenja Konvencije i ušao u nedopuštenu sferu stvaranja prava. ${ }^{26}$ Međutim, a kako ćemo vidjeti u nastavku rada, Sud to nije učinio, već je vrlo ograničeno jamčio pravo na zdravstvenu zaštitu, isključivo koristeći prihvaćena načela tumačenja. ${ }^{27}$

Konačno, još jedan dokument Vijeća Europe koji se bavi pitanjem zdravstvene skrbi jest Konvencija o zaštiti ljudskih prava i dostojanstva ljudskog bića u pogledu primjene biologije i medicine (Konvencija o ljudskim pravima i biomedicini) koja je potpisana 4. travnja 1997. godine, a na snagu je stupila 1. prosinca 1999. godine. Člankom 3. reguliran je pravičan pristup zdravstvenoj zaštiti odgovarajuće kvalitete. Iako se Europski sud za ljudska prava u nekoliko svojih odluka pozivao na Konvenciju o ljudskim pravima i biomedicini, nikada se nije pozivao na pravo na pravičan pristup zdravstvenoj zaštiti. ${ }^{28}$

Mashood Baderin and Robert McCorquodale (eds), Economic, Social and Cultural Rights in Action (OUP, Oxford, 2007); Daphne Barak-Erez and Aeyal Gross (eds), Exploring Social Rights Between Theory and Practice (Hart Publishing, Oxford, 2007); Robin Churchill and Urfan Khaliq, "The Collective Complaints System of the European Social Charter: An Effective Mechanism for Ensuring Compliance with Economic and Social Rights?' (2004) 15 (3) EJIL 417.

22 Theo Van Boven, 'Categories of Rights' u Daniel Moeckli (ed), International Human Rights Law (OUP, Oxford, 2010), 173-188; Sandra Fredman, Human Rights Transformed: Positive Rights and Positive Duties (OUP, Oxford, 2008), 66-91.

23 Teheranska proklamacija, dio Završnog akta usvojenog na Svjetskoj konferenciji o ljudskim pravima, održanoj u Teheranu od 22. travnja do 13. svibnja 1968. u U. N. Doc. A/CONF. 32/41, (13); Opća skupština Ujedinjenih naroda, Bečka deklaracija i program djelovanja, usvojeni na Svjetskoj konferenciji o ljudskim pravima, Beč, 14. - 25. lipnja 1993. potvrđeni na 48. zasjedanju Opće skupštine Ujedinjenih naroda, A/CONF.157/23, (5).; Opća skupština Ujedinjenih naroda, 2005 World Summit Outcome: resolution/adopted by the General Assembly, 24 October 2005, A/RES/60/1 (121); Opća skupština Ujedinjenih naroda, Human Rights Council: resolution/adopted by the General Assembly 3 April 2006, A/RES/60/251, preambula (3).

24 Prava solidarnosti smatrala su se pravima 'treće generacije'. Prijedlog, odnosno ideju, o tri generacije prava izložio je Karel Vasek u Karel Vasek, 'A 30-Year Struggle: The Sustained Efforts to give Force of Law to the UDHR' (1977) 30(11) UNESCO Courier 29.

25 Henry Shue, Basic Rights, Subsistence, Affluence and U.S. Foreign Policy (Princeton University Press, Princeton, 1980); Asbjørn Eide, UN Special Rapporteur for the Right to Food, The Right to Adequate Food as a Human Right: Final Report submitted by Asbjørn Eide (1987) UN Doc E/CN.4/Sub.2/1987/23, 67-69; Asbjørn Eide, 'Economic, Social and Cultural Rights as Human Rights' u: Asbjørn Eide et al. (ur.), Economic, Social and Cultural Rights, A textbook (Kluwer Law International 2001) 23-24; Ida Elisabeth Koch, ‘The Justiciability of Indivisible Rights' (2003) 72 Nordic Journal of International Law 3.

26 Kanstantin Dzehtsiarou, European consensus and the legitimacy of the European court of human rights (CUP, Cambridge, 2015); George Letsas, A Theory of Interpretation of the European Convention on Human Rights (OUP, Oxford, 2009); Lord Lester of Herne Hill 'Universality versus Subsidiarity: A Reply' (1998) 1 EHRLR 73.

27 Senden (n 14); George Letsas 'The ECHR as a living instrument: Its meaning and legitimacy' u Andreas Føllesdal, Brigit Peters and Geir Ulfstein (eds) Constituting Europe: The European Court of Human Rights in a National, European and Global Context (CUP, Cambridge, 2013); Kanstantin Dzehtsiarou, 'What is Law for the European Court of Human Rights?' (2017) 49 (1) Georgetown Journal of International Law 89; Wisniewski (b 14). 


\subsection{KONVENCIJA I PRAVO NA ZDRAVSTVENU ZAŠTITU}

Kao što je već naglašeno, Europska konvencija za zaštitu ljudskih prava i temeljnih sloboda u svom katalogu ljudskih prava ne predviđa pravo na zdravstvenu zaštitu. Unatoč tome što takva zaštita nije predviđena, nepružanje zdravstvene zaštite, odnosno nepružanje određenog standarda zaštite moglo bi predstavljati povredu čl. 2., 3. i 8. Konvencije.

Razmatrajući razne predmete vezane uz zaštitu osoba u kontekstu zdravstvene skrbi u kojima je došlo do povrede čl. 2., ${ }^{29}$ Sud je donio nekoliko zaključaka. Primjerice, doći će do povrede čl. 2. ako država ne donese propise koji će obvezati bolnice da usvoje mjere za zaštitu života. Obveza je države da osigura učinkovito funkcioniranje regulatornog zdravstvenog sustava te ako je država osigurala visoke stručne standarde vezane uz zdravstvo, a unatoč tome je došlo do nesavjesnog liječenja, takvo postupanje pojedinca neće dovesti do odgovornosti države za povredu prava na život. Do povrede čl. 2. doći će u slučaju uskraćivanja zdravstvene zaštite koju se obvezala pružiti država, kao i u slučaju propusta države da pacijentu omogući pristup hitnom tretmanu koji bi mu mogao spasiti život. Da bi se postupanje države smatralo onemogućavanjem pristupa hitnom tretmanu, Sud je postavio nekoliko kriterija koji moraju biti kumulativno ispunjeni. Prvo, propust, odnosno pogreška zdravstvenog djelatnika mora prelaziti puku liječničku pogrešku ili nesavjesno liječenje. Dalje, mora biti objektivno utvrđeno da je takva nepravilnost sustavna ili strukturalna, odnosno da se može pripisati vlastima. Treće, mora postojati uzročno-posljedična veza između nepravilnosti i nastale štete. Zadnje, takva nepravilnost mora biti posljedica propusta države da osigura učinkovito funkcioniranje regulatornog okvira. ${ }^{30}$

Člankom 8. Konvencije zaštićeno je pravo na poštovanje privatnog i obiteljskog života, a samim time i tjelesni i moralni integritet osobe koji spada u sferu njezina privatnog života. Tim člankom državama je nametnuta pozitivna obveza da svojim građanima osigura pravo na učinkovito poštovanje njihova tjelesnog i moralnog integriteta te usvajanje posebnih mjera koje uključuju osiguranje djelotvornih i dostupnih sredstava koja se odnose na zaštitu prava na privatnost. Pod polje primjene čl. 8. spadaju i pitanja prisilnog liječenja, reproduktivnih prava, zaštite osoba s duševnim bolestima, pružanja zdravstvene skrbi i sl. ${ }^{31}$ Vezano uz pitanja reproduktivnih prava, Sud pod polje primjene čl. 8. svrstava pitanje pobačaja u slučaju kada je pobačaj nužan zbog zaštite zdravlja, prenatalna testiranja, okolnosti poroda, postupak sterilizacije itd., iako se, kao što će biti prikazano supra, o navedenim pitanjima raspravlja i u kontekstu čl. 3. Prisilna liječenja i obvezne medicinske pretrage prema odlukama Suda mogu predstavljati miješanje u pravo na

29 Vidi npr. predmete LCB $v$ The United Kingdom (1999) 27 EHRR 212; Roche $v$ The United Kingdom (2006) 42 EHRR 30; Erikson $v$ Italy (2000) 29 EHRR CD152; Calvelli and Ciglio v Italy, App no 32967/96, (ECtHR, 17 January 2002); Nitecki v Poland App no 65653/01 (ECtHR, 21 March 2002); Pentiacova and others v Moldova (2005) 40 EHRR SE23; Mehmet Sentürk and Bekir Sentürk v Turkey (2013) 60 EHRR 4; Šilih v Slovenia (2009) 49 EHRR 37.

30 Alastair Mowbray, The Development of Positive Obligations under the European Convention on Human Rights by the European Court of Human Rights (Hart Publishing2004), 22; Vodič kroz članak 2. Konvencije: Pravo na život (Vijeće Europe, ažuriran 31. prosinca 2018.) 12-13 <https://uredzastupnika.gov.hr/ UserDocsImages//dokumenti/Edukacija//Vodi\%C4\%8D\%20kroz\%20 \%C4\%8Dlanak\%202.\%20Konvencije.pdf> pristupljeno 13. srpnja 2021. no 32647/96 (ECtHR, 1 July 1998); Sentges v Netherlands, App no 27677/02 (ECtHR, 8 July 2003); Vasileva v Bulgaria (2003) 40 EHHR 681; İbrahim Keskin v Turkey, App no 10491/12 (ECtHR, 27 March 2018); Eryiğit v Turkey, App no 18356/11 (ECtHR, 10 April 2018); Jurica v Croatia, App no 30376/13 (ECtHR, 2 May 2017);Hristozov and others v Bulgaria, App no 47039/11 and 358/12 (ECtHR, 13 November 2012)Durisotto v Italy, App no 62804/13 (ECtHR, 6 May 2014); Gard and others v The United Kingdom, App no 39793/17 (ECtHR, 27 June 2017). 
privatnost, kao i nepružanje informacija o zdravstvenim rizicima od strane države ili propust države da osigura sredstva kojima bi se naknadila šteta nastala zbog medicinske pogreške za koju je ona odgovorna. Što se tiče pitanja zdravstvene skrbi, državama su nametnute pozitivne obveze poput omogućavanja provedbe postupka u slučajevima nesavjesnog liječenja, donošenja mjera kojima se štiti tjelesni integritet, pravilne provedbe zakonodavnog okvira koji se odnosi na pitanje tjelesnog integriteta, objektivnosti vještaka te učinkovitosti pravnih lijekova u sudskim postupcima koji se vode zbog povrede tjelesnog integriteta. ${ }^{32}$

Nepružanje adekvatne zdravstvene skrbi u nekim slučajevima može predstavljati nečovječno ili ponižavajuće postupanje koje će dovesti do povrede čl. 3. Takvo postupanje mora zadovoljiti određen stupanj okrutnosti kako bi spadalo pod polje primjene tog članka te će se u sljedećem poglavlju analizirati presude Suda koje se odnose na čl. 3., a vezane su uz nepružanje zdravstvene skrbi izvan konteksta zadržavanja.

\section{NEPRUŽANJE ZDRAVSTVENE SKRBI KAO POVREDA ČLANKA 3. KONVENCIJE IZVAN KONTEKSTA ZADRŽAVANJA}

Članak 3. Konvencije razvio je vrlo bogatu praksu Suda. Unatoč apsolutnom karakteru navedenog članka, Sud se u svojim presudama nije zadržavao samo na najtežim oblicima lošeg postupanja prema pojedincima već je razvio i bogatu praksu vezanu uz primjerice aktivno tjelesno zlostavljanje osoba lišenih slobode, uvjete u zatvorima te zdravstvenu skrb koja se pruža osobama lišenim slobode. ${ }^{33}$ Kao što je već napomenuto, glavni predmet ovog rada neće biti pružanje zdravstvene skrbi u pritvoru odnosno zatvoru ili u drugim ustanovama za smještaj osoba lišenih slobode, gdje su podnositelji zahtjeva u potpunosti pod nadzorom države, a kojih je pred Sudom bio popriličan broj. Kada je riječ o zdravstvenoj skrbi u pritvorima i zatvorima, razvoj je sudske prakse u pogledu prava na zadovoljavajuće uvjete pritvora i pravo na zdravstvenu zaštitu osoba lišenih slobode prema čl. 3. konstantan. S druge strane, većina predmeta koji se odnose na pružanje zdravstvene skrbi izvan konteksta zadržavanja nije prošla ni fazu odlučivanja o dopuštenosti, odnosno o meritumu se nije ni raspravljalo. Međutim, ipak postoji određeni broj predmeta u kojima je Sud raspravljao i odlučivao o meritumu a vezano uz pružanje zdravstvene skrbi izvan konteksta zadržavanja te će isti biti prikazani u nastavku.

\subsection{PRAKSA SUDA U PREDMETIMA KOJI SE ODNOSE NA PRUŽANJE ZDRAVSTVENE SKRBI IZVAN KONTEKSTA ZADRŽAVANJA}

Središnji dio rada prikazat će razvoj sudske prakse u predmetima gdje su podnositelji zahtjeva tvrdili kako im je nepružanje ili nedovoljna zdravstvena skrb povrijedilo prava zajam-

32 Vodič kroz članak 8. Europske konvencije o ljudskim pravima - pravo na poštovanje privatnog i obiteljskog života, doma i dopisivanja (Vijeće Europe, ažuriran 31. kolovoza 2018) 18-24. <https://uredzastupnika.gov.hr/edukacija-o-konvenciji-137/ vodici/546> pristupljeno 6. svibnja 2020.

33 Prisoner's helath related rights: factsheet (European Court of Human Rights, July 2020) <https://echr.coe.int/Documents/ FS_Prisoners_health_ENG.pdf> pristupljeno 10. rujna 2020. 
čena čl. 3. Konvencije izvan konteksta zadržavanja. Ovo smatramo značajnim s obzirom na to da Konvencija, a posljedično niti čl. 3. ne sadrže u sebi pravo na zdravstvenu zaštitu kao takvu, niti se može pretpostaviti koje su to situacije u kojima će podnositelji tvrditi povredu čl. 3 . zbog neadekvatne zdravstvene skrbi izvan konteksta zadržavanja. Stoga je zanimljivo vidjeti u kojim se to predmetima Sud bavio ispitivanjem povrede čl. 3. zbog neadekvatne zdravstvene skrbi izvan konteksta zadržavanja, odnosno izvan ustanova u kojima se nalaze osobe lišene slobode. Navedene predmete podijelit ćemo u nekoliko skupina, s obzirom na zahtjeve podnositelje i to na sljedeći način: predmeti koji se odnose na deportaciju podnositelja u zemlje s nezadovoljavajućom zdravstvenom skrbi, reproduktivna prava te predmeti koji se odnose na zdravstvenu skrb djece i maloljetnika.

\section{1. a) Deportacija podnositelja kao povreda članka 3.}

Ključni predmeti u kojima se pojavilo pitanje povrede čl. 3. zbog deportacije podnositelja u zemlju koja im ne može pružiti zadovoljavajuću zdravstvenu skrb su D. protiv Ujedinjene Kraljevine $^{34}$ i N. protiv Ujedinjene Kraljevine ${ }^{35}$ a iz kojih se može iščitati problematika uključivanja, pa čak i na minimalnoj razini, prava na zdravstvenu skrb u okvire konvencijskih građanskih i političkih prava.

Konkretni predmeti odnose se na deportaciju podnositelja u zemlje iz kojih su prvobitno došli u Ujedinjenu Kraljevinu. Naime, u oba predmeta podnositelji zahtjeva tvrdili su kako će doći do povrede čl. 3. zbog nedostatka odgovarajuće zdravstvene skrbi u zemljama u koje su trebali biti deportirani. Zanimljivo je spomenuti kako je upravo predmet D. protiv Ujedinjene Kraljevine dao naslutiti kako je Sud spreman baviti se pravom na zdravstvenu skrb i pravima iz zdravstvene zaštite. Iako su u ovom slučaju okolnosti bile posebne, isti je značajan s obzirom na to da je dao zanimljive pokazatelje tumačima Konvencije.

Naime, u predmetu D. protiv Ujedinjene Kraljevine kod podnositelja zahtjeva, državljanina St. Kittsa, pronađena je značajna količina kokaina po dolasku u Ujedinjenu Kraljevinu te je osuđen zbog ilegalnog uvoza kontrolirane droge i osuđen na šest godina zatvora. Kad je pušten iz zatvora, D. je bio u poodmakloj fazi AIDS-a te mu je britanska dobrotvorna organizacija osigurala smještaj i njegu, kao i liječenje njegova stanja. Imigracijske vlasti naredile su D.-ovu deportaciju u St. Kitts, a njegov zahtjev za sudskim preispitivanjem te odluke i naknadna žalba odbijene su. Konačno, D. se obratio Sudu, tvrdeći da bi njegovom deportacijom došlo do povrede čl. 3., s obzirom na to da na St. Kittsu neće dobiti odgovarajuću zdravstvenu skrb niti ima obitelj koja bi se mogla brinuti za njega.

Odlučujući o navodnoj povredi čl. 3., Sud je naglasio kako si, s obzirom na temeljnu važnost čl. 3., mora pridržati dovoljnu fleksibilnost da bi se pozabavio primjenom tog članka u drugim kontekstima koji bi mogli nastati. Stoga Sud nije spriječen da detaljno prouči zahtjev podnositelja zahtjeva prema čl. 3., iako izvor rizika odnosno nedostatak liječenja u zemlji prijema proizlazi iz čimbenika koji ne mogu biti izravno ili neizravno pripisani javnim vlastima te zemlje ili koji, uzeti u obzir sami po sebi ne krše standarde iz tog članka. Ograničiti primjenu čl. 
3. na ovaj način značilo bi potkopati apsolutni karakter njegove zaštite. ${ }^{36}$ Slijedom toga, Sud je nakon razmatranja činjenica slučaja našao da bi deportacija podnositelja u St. Kitts dovela do povrede njegovih prava zajamčenih čl. 3 . Konvencije.

Iako je Sud naglasio da pojam nečovječnog postupanja ima posebno značenje zbog iznimnih okolnosti slučaja i da se u načelu na pravo na zdravstvenu skrb podnositelji ne mogu pozivati, mnogim budućim podnositeljima zahtjeva (i tumačima Konvencije) ova presuda se činila kao otvaranje prostora za pozivanje na pravo na (određeni stupanj) zdravstvene zaštite prema Konvenciji. Međutim, a kako će se vidjeti supra, predmet $D$. nije uspostavio minimalno temeljno pravo na liječenje umirućih pacijenata o kojima se nitko ne brine ili još manje presedan, kao što se moglo očekivati. ${ }^{37}$

U vrlo sličnom zahtjevu, $N$. protiv Ujedinjene Kraljevine, Sud je odlučno odbio zahtjev podnositeljice, HIV pozitivne državljanka Ugande, koja je tvrdila da ako bude vraćena u Ugandu, neće imati pristup prijeko potrebnom liječenju. U ovom je predmetu N., nakon ulaska u Ujedinjenu Kraljevinu, dijagnosticirana kao HIV pozitivna. Također je razvila brojne bolesti povezane s HIV-om. Njezino se stanje stabiliziralo po primanju lijekova i pristupu medicinskim ustanovama u Ujedinjenoj Kraljevini. Državna tajnica, nakon što je odbila N.-inu zamolbu za azil, odbacila je i njezin zahtjev prema čl. 3. utvrdivši da su svi glavni antivirusni lijekovi bili dostupni u Ugandi po visoko subvencioniranim cijenama i da je liječenje HIV-a u Ugandi usporedivo s bilo kojim drugom afričkom zemljom. N. je tvrdila da bi, s obzirom na njezinu bolest i nedostatak dostupnog liječenja, socijalne podrške ili njege u Ugandi, njezin povratak prouzročio akutne fizičke i mentalne patnje, praćene ranom smrću te posljedično da bi predstavljale povredu prava iz čl. 3. Ove činjenice, ne samo da su slične onima iz predmeta D., već je riječ o podnositeljici koja nije počinila nikakvo kazneno djelo u Ujedinjenoj Kraljevini. Međutim, Sud je, odlučujući o tome hoće li deportacija predstavljati povredu čl. 3. Konvencije naglasio:

„Iako mnoga prava koja sadrži imaju implikacije socijalne ili ekonomske prirode, Konvencija je u osnovi usmjerena na zaštitu građanskih i političkih prava. Nadalje, Konvenciji kao cjelini svojstveno je traženje pravedne ravnoteže između zahtjeva općeg interesa zajednice i zahtjeva zaštite temeljnih prava pojedinca. Napredak medicinske znanosti, zajedno sa socijalnim i ekonomskim razlikama među zemljama, podrazumijeva da se razina liječenja dostupna u državi ugovornici i zemlji podrijetla može znatno razlikovati. Iako je potrebno, s obzirom na temeljnu važnost čl. 3. u sustavu Konvencije, da Sud zadrži određeni stupanj fleksibilnosti kako bi spriječio izručivanje u vrlo iznimnim slučajevima, čl. 3. ne obvezuje državu ugovornicu da ublaži razlike kroz pružanje besplatne i neograničene zdravstvene zaštite svim strancima. Suprotno odlučivanje prekomjerno bi opteretilo države ugovornice." ${ }^{38}$

Ovakvo razmišljanje Suda popuno je razumljivo no pomalo neočekivano nakon odluke u predmetu $D .{ }^{39}$ Stoga ne čudi i izdvojeno mišljenje trojice sudaca koji su naglasili kako „temeljita analiza odluka domaćih sudova navodi nas na zaključak da postoje značajni razlozi za

36 D. $v$ The United Kingdom (n 34) 49.

37 Marochini 'Council of Europe and the Right to Healthcare' (n 6), 744-745.

38 N.v The United Kingdom (n 35) 44.

39 Iako prava zajamčena čl. 3. nisu nikada podložna derogaciji i spadaju u apsolutna prava, postavlja se pitanje je li Sud ovakvim razilaženjem u dvije presude sličnog činjeničnog stanja umanjio apsolutni karakter čl. 3., odnosno dopustio državama određenu slobodu procjene, što se smatra apsolutno neprihvatljivim u predmetima koji se odnose na prava zajamčena čl. 3. Konvencije. 
vjerovanje da se podnositeljica zahtjeva suočava sa stvarnim rizikom zabranjenog postupanja u svojoj zemlji. Štoviše, ovaj slučaj ispunjava test „vrlo izuzetnih okolnosti“ kako je utvrđeno u D. protiv Ujedinjene Kraljevine... Doduše, Sud nikada nije utvrdio kršenje u predmetima odlučenim nakon D. protiv Ujedinjene Kraljevine. Međutim, u svim se slučajevima odlučivalo o činjenicama koje se mogu razlikovati od onih u tom predmetu i od onih u ovom predmetu..." 40 „Bez tumačenja opsega čl. 3. Konvencije drugačije od Suda u slučaju D. protiv Ujedinjene Kraljevine, kršenje bi se u ovom predmetu moglo utvrditi u svjetlu krajnjih činjenica... Drugim riječima, utvrđivanje potencijalne povrede čl. 3 . u ovom slučaju ne bi predstavljalo proširenje iznimne kategorije slučajeva koju zastupa $D$. protiv Ujedinjene Kraljevine. Prema našem mišljenju, razlikovanje ovog slučaja od slučaja D. protiv Ujedinjene Kraljevine je pogrešno.“41

Nakon ova dva, možemo reći ključna predmeta, iz kojih je vidljivo kako Sud nije zauzeo jasan stav o navedenom pitanju, spomenuti ćemo još nekoliko predmeta sličnog činjeničnog stanja. Prvi je S. J. protiv Belgije ${ }^{42}$ gdje je Veliko vijeće donijelo odluku o prijateljskom rješenju. U konkretnom predmetu, podnositeljica zahtjeva, HIV pozitivna nigerijska državljanka, tvrdila je da postoje ozbiljne i utvrđene osnove za vjerovanje da će se, ako bude vraćena u Nigeriju, suočiti sa stvarnim rizikom da bude podvrgnuta nečovječnom i ponižavajućem postupanju, s obzirom na činjenicu da joj je složena antivirusna terapija koju je primala u Belgiji jamčila preživljavanje a ista nije dostupna u Nigeriji. Ona je također tvrdila da bi odsutnost liječenja rezultirala njezinom preranom smrću u posebno nečovječnim uvjetima, posebno uzimajući u obzir prisutnost njezino troje malodobne djece. Sud je izbrisao zahtjev s popisa predmeta (u skladu s čl. 37. Konvencija), s obzirom na to da je postignuto prijateljsko rješenje između belgijske vlade i podnositeljice zahtjeva. Naime, podnositeljici zahtjeva i njezinoj djeci izdane su dozvole boravka kojima se odobrava na neodređeno vrijeme ostanak u Belgiji. U prijedlogu prijateljskog rješenja koji je Sud primio od belgijske vlade u kolovozu 2014. godine posebno su naglašeni snažni humanitarni razlozi u korist reguliranja statusa prebivališta podnositeljice zahtjeva i njezine djece. Ovaj predmet je zanimljiv zbog dvaju razloga. Prvo, Vijeće je u svojoj presudi odlučilo kako u slučaju izručenja ne bi došlo do povrede čl. 3., iako je našlo povredu čl. 3. zajedno s čl. 13. zbog nedostatka učinkovitih pravnih sredstava u Belgiji. Odluka Vijeća, čini se, slijedi stav Suda iz predmeta N. protiv UK, gdje se čini gotovo nemogućim dokazivanje od strane podnositelja kako im prijeti stvaran i realan rizik od zabranjenog postupanja u slučaju izručenja, odnosno postojanje „vrlo izuzetnih okolnosti“. ${ }^{43} \mathrm{~S}$ druge strane, brisanje zahtjeva s liste predmeta naišlo je na neodobravanje, kako od pravnika koji se bave Konvencijom, ${ }^{44}$ tako i jednog suca ${ }^{45}$ koji je odlučivao u sastavu Velikog vijeća, koji su smatrali kako je Veliko vijeće

$40 \quad$ N. v The United Kingdom (n35) 15 izdvojenog mišljenja sudaca Tulkens, Bonello i Spielmann.

41 Ibid 24-25.

42 App no 70055/10 (ECtHR 19 March 2015). Zanimljiv je također i predmet Yoh-Ekale Mwanje v Belgium (2011) 56 EHRR 1140. gdje je Vijeće odlučilo kako u slučaju deportacije HIV pozitivnog kamerunskog državljanina neće doći do povrede čl. 3., no odluka je donesena uz izdvojeno suglasno mišljenje 6 sudaca. Navedeno izdvojeno mišljenje svakako je zanimljivo jer suci naglašavaju iznimne teškoće pri procjenjivanju hoće li izručenje predstavljati nečovječno i ponižavajuće postupanje. 30 April 2015) <https://strasbourgobservers.com/2015/04/30/s-j-v-belgium-missed-opportunity-to-fairly-protect-seriouslyill-migrants-facing-expulsion/> pristupljeno 13. srpnja 2021. 
propustilo priliku da zauzme čovječan i razuman stav prema ranjivoj kategoriji teško bolesnih migranata.

Još jedan značajan predmet vezan uz moguću povredu čl. 3. u slučaju deportacije jest $P a-$ poshvili protiv Belgije ${ }^{46} \mathrm{u}$ kojem je 13. prosinca 2016. presudu donijelo Veliko vijeće. Ovaj slučaj odnosio se na nalog za deportaciju podnositelja zahtjeva u Gruziju, uz zabranu ponovnog ulaska u Belgiju. Podnositelj zahtjeva patio je od nekoliko ozbiljnih medicinskih stanja, uključujući kroničnu limfocitnu leukemiju i tuberkulozu, a koji su navedeni kao posebno značajni razlozi za vjerovanje da će, ako bude protjeran u Gruziju, ondje se suočiti sa stvarnim i ozbiljnim rizikom od nečovječnog i ponižavajućeg postupanja i prerane smrti. Također se žalio, a što smatramo bitnim naglasiti, da će njegovo izručenje u Gruziju, o čemu je odluka donesena zajedno s desetogodišnjom zabranom ponovnog ulaska u Belgiju, rezultirati njegovom odvojenosti od obitelji koja je dobila dopuštenje da ostane u Belgiji a koji mu predstavljaju najveći, a ujedno i jedini izvor potpore. Podnositelj zahtjeva umro je u lipnju 2016. Njegova supruga i troje djece nakon toga su nastavili njegov slučaj pred Sudom. ${ }^{47}$

U svojoj odluci, Veliko vijeće je zaključilo kako bi došlo do kršenja čl. 3. u slučaju deportacije podnositelja u Gruziju te da belgijske vlasti nisu procijenile rizik s kojim se podnositelj susreće u svjetlu informacija koje se odnose na njegovo zdravstveno stanje i postojanje odgovarajućeg tretmana u Gruziji kao i kršenje čl. 8. s obzirom na to da nije bilo adekvatne procjene belgijskih vlasti o utjecaju deportacije na njegovo pravo na poštovanje obiteljskog života a s obzirom na njegovo zdravstveno stanje. Sud je posebno primijetio da medicinska situacija podnositelja zahtjeva, koji je bolovao od vrlo ozbiljnih bolesti i čije je stanje bilo opasno za život, nije ispitano od belgijskih vlasti u kontekstu njegovih zahtjeva za reguliranje statusa boravka. U konkretnom predmetu čini se da je najveća kritika Suda upućena belgijskim vlastima zbog nedostatka procjene rizika, odnosno utjecaja deportacije kako na zdravstvenu skrb podnositelja tako i na njegov obiteljski život.

Konačno, predmet gdje se još čeka konačna odluka s obzirom na to da je upućen na odlučivanje Velikom vijeću je Savran protiv Danske. ${ }^{48}$ Isti se odnosi na prigovor turskog državljanina da bi zbog njegova mentalnog zdravlja njegova prava bila povrijeđena ako bi se vratio u Tursku. Naime, psihijatri su preporučili pomno praćenje podnositelja zahtjeva kako bi njegovo liječenje bilo učinkovito i omogućilo reintegraciju u društvo nakon što je počinio ozbiljan prekršaj. Unatoč tome, danske vlasti donijele su odluku o njegovoj deportaciji u Tursku. U svojoj presudi od 1. listopada 2019., Vijeće je s četiri glasova za i tri protiv zaključilo, a pozivajući se na presudu u predmetu Paposhvili protiv Belgije, da bi deportacija podnositelja zahtjeva u Tursku, bez dobivanja adekvatnih jamstva o njegovoj njezi u Turskoj, prekršila prava podnositelja iz čl. 3. Naime, Sud je također sumnjao da bi podnositelj zahtjeva primao odgovarajuću njegu u Turskoj. Dana 27. siječnja 2020. prihvaćen je zahtjev danske vlade da se slučaj proslijedi Velikom vijeću.

46 Paposhvili v Belgium, App no 41738/10 (ECtHR, 13 December 2016)

47 Odluku Suda kojom se njegovoj supruzi i djeci dopušta nastavljanje postupka pred Sudom posebno je zanimljiva ako se uzme u obzir odluka Suda u predmetu IG, MK and RH v Slovakia, App no 15966/04 (ECtHR, 13 November 2012) u kojem je Sud utvrdio kako su prava zajamčena čl. 3. i 8. usko povezana s osobom prvobitne podnositeljice zahtjeva te se ne mogu smatrati prenosivima. Stoga je Sud utvrdio da djeca podnositeljice zahtjeva nemaju pravo nastaviti postupak umjesto svoje majke. S obzirom na to da je u konkretnom predmetu supruzi podnositelja i njihovoj djeci dopušten ostanak u Belgiji, ostaje nejasno zašto je u ovom predmetu Veliko vijeće dopustilo daljnje ispitivanje povreda čl. 3. i 8. 
Ovaj predmet čini se upravo na tragu D. protiv Ujedinjene Kraljevine te ostaje vidjeti hoće li se Veliko vijeće složiti s tijesnom većinom Vijeća ili sa suprotnim mišljenjima troje sudaca koji su naglasili: „(...) U predmetu Paposhvili protiv Belgije Veliko je vijeće naglasilo vrlo strogu postojeću sudsku praksu prema kojoj je članak 3. primjenjiv samo ako je stranac koji ima biti deportiran 'blizu smrti'. U tom kontekstu, Veliko vijeće smatralo je potrebnim razjasniti što podrazumijeva pod 'drugim vrlo iznimnim okolnostima'."49 Stoga su izdvojili odlomak 183. navedene presude gdje Sud smatra da se pod „drugim vrlo iznimnim okolnostima“ u smislu presude u predmetu $N$. protiv Ujedinjene Kraljevine, a koji mogu pokrenuti pitanje na temelju čl. 3., mogu smatrati situacije koje uključuju uklanjanje ozbiljno bolesne osobe kojoj su dokazani značajni razlozi za vjerovanje da će se, iako joj ne prijeti neposredna opasnost od smrti, zbog odsutnosti odgovarajućeg liječenja u zemlji prijema ili zbog nedostatka pristupa takvom tretmanu, suočiti sa stvarnim rizikom kao i izložiti ozbiljnom, brzom i nepovratnom pogoršanju njegova zdravstvenog stanja što će rezultirati intenzivnom patnjom ili značajnom smanjenju očekivanog trajanja života. Sud ističe da ove situacije odgovaraju visokom pragu za primjenu čl. 3. Konvencije u slučajevima koji se odnose na deportaciju stranaca koji pate od teških bolesti.

Mišljenje je sudaca koji su napisali zajedničko izdvojeno mišljenje kako se većina u ovom slučaju nije vjerno pridržavala i primijenila nedavnu i jednoglasnu presudu Paposhvili na činjenice slučaja. Suprotno tome, smatraju suci koji su napisali izdvojeno mišljenje, većina je iskoristila prvu dostupnu priliku za daljnje širenje opsega čl. 3. u ovom osjetljivom području, čime je u praksi širom otvorila vrata koja je Veliko vijeće namjerno i zbog zdravih pravnih i političkih razloga odlučilo samo malo otvoriti u usporedbi s prethodnom strogom sudskom praksom.

\section{1. b) Reproduktivna prava}

Sljedeća skupina predmeta u kojima se pojavilo pitanje povrede čl. 3. zbog neadekvatne zdravstvene skrbi izvan konteksta zadržavanja tiče se reproduktivnih prava podnositeljica, gdje smatramo najznačajnijim predmete koji se tiču prisilne sterilizacije žena romske nacionalnosti.

Međutim, prvi predmet koji će biti analiziran je R. R. protiv Poljske $e^{50}$ u kojem je osnovni problem bila nemogućnost podnositeljice na prekid trudnoće, unatoč zdravstvenim rizicima koji su prijetili u slučaju zadržavanja trudnoće. U navedenom predmetu podnositeljica zahtjeva bila je u 18. tjednu trudnoće kada je njezin ginekolog uočio cistu na fetusovu vratu te ju uputio da obavi daljnje pretrage. Unatoč strogoj pravnoj i zakonskoj regulaciji obavljanja pobačaja, postojala je mogućnost da se, ako bi se takve pretrage obavile na vrijeme, prekine trudnoća. Podnositeljica je tijekom razdoblja od osam tjedana pregledana od strane 16 liječnika, obavila pet pregleda na ultrazvuku i bila dva puta hospitalizirana, međutim nijednom nisu bili obavljeni potrebni prenatalni genetski testovi već su isti obavljeni tek u 23. tjednu trudnoće. Nalazi su stigli nakon dva tjedna, potvrđujući kako fetus boluje od genetskih abnormalnosti te se podnositeljica obratila lokalnoj bolnici zahtijevajući pobačaj. S obzirom na to da od bolnice nije dobila odgovor, ponovno je poslala zahtjev nekoliko dana kasnije, međutim dobila

49 Ibid, Izdvojena mišljenja sudaca Kjølbro, Motoc i Mourou-Vikströ 6. 
je odgovor kako pobačaj u 25. tjednu trudnoće više nije moguć. Posljedično, podnositeljica je rodila djevojčicu s Turnerovim sindromom. Također, godinu dana kasnije, njezin ginekolog izašao je u javnost s podacima o njezinu zdravlju i negativnim komentarima o njezinoj osobnosti. Slijedom svega navedenog, podnositeljica se obratila Sudu pozivajući se na povredu čl. 3. kao rezultat namjernog propusta liječnika da joj pruže nužan medicinski tretman u obliku pravovremenih prenatalnih pregleda koji bi joj omogućili da donese odluku hoće li nastaviti ili prekinuti trudnoću u roku utvrđenom domaćim zakonskim uređenjem. Također se žalila da su se liječnici odnosili s prijezirom prema njoj, opetovano je kritizirajući zbog njezinih napora na provođenju prenatalnih testova i zbog činjenice da je pobačaj predvidjela kao moguće rješenje svoje nevolje. Sud je, utvrđujući povredu čl. 3., odlučio kako se patnja podnositeljice zahtjeva, i prije nego što su postali poznati rezultati testova kao i nakon tog datuma, dodatno pogoršala činjenicom da su dijagnostičke usluge koje je ranije zatražila bile cijelo vrijeme dostupne i da je, prema domaćem zakonu, imala pravo njima se koristiti. Sud je izrazio žaljenje zbog odnosa liječnika prema podnositeljici zahtjeva te se složio sa stajalištem poljskog Vrhovnog suda da je podnositeljica zahtjeva ponižena. Zaključno, Sud je smatrao da je patnja podnositeljice zahtjeva dosegnula minimalnu razinu okrutnosti prema čl. 3. Konvencije čime je isti i povrijeđen.

Okrećući se predmetima vezanim uz prisilnu sterilizaciju žena romske nacionalnosti, spomenut ćemo predmet $V$. C. protiv Slovačke, ${ }^{51}$ gdje je podnositeljica zahtjeva sterilizirana u bolnici tijekom porođaja svog drugog djeteta. Prije poroda koji se morao obaviti carskim rezom, podnositeljica je upitana želi li još djece, a na njezin potvrdan odgovor doktor joj je objasnio kako bi sljedeće dijete moglo biti u životnoj opasnosti. Tijekom trajanja poroda, podnositeljica je bila prisiljena potpisati obrazac kojim pristaje na sterilizaciju navodeći kako su, ako ne potpiše, ugroženi životi nje i djeteta, iako zapravo nije znala značenje tog pojma. Nakon operacije bila je smještena u posebnoj sobi u kojoj su boravile samo žene romske nacionalnosti. Podnositeljica je zbog postupka sterilizacije izbačena iz romske zajednice, a zbog nemogućnosti da ponovno zatrudni rastala se od svog muža. Sud je utvrdio povredu čl. 3., tvrdeći da sterilizacija predstavlja ozbiljno miješanje u reproduktivno stanje osobe te utječe na integritet pojedinca. ${ }^{52}$

Nastavno na ovaj predmet, sljedeći značajan je I. G., M. K. i R. H. protiv Slovačke ${ }^{53}$ a koji se odnosio na tri žene romskog podrijetla koje su se žalile na sterilizaciju bez njihova punog i informiranog pristanka, a nakon koje je uslijedila istraga o njihovoj sterilizaciji koja nije bila temeljita, poštena ili učinkovita. Također su tvrdile da je njihovo etničko podrijetlo imalo presudnu ulogu u sterilizaciji. Sud je utvrdio povredu prava iz čl. 3. kako u materijalnom tako i u postupovnom aspektu kod prvih dviju podnositeljica zahtjeva. Nadalje je utvrdio kršenje prava iz čl. 8. kad je riječ o prvim dvjema podnositeljicama zahtjeva dok je za treću podnositeljicu

51 VCv Slovakia,App no 18968/07 (ECtHR, 8 November 2011).Prvi predmet pred Sudom u kojima su pripadnice romske nacionalnosti podnijele zahtjev zbog prisilile sterilizacije je KH and others v Slovakia ((2009) 49 EHRR 857). U konkretnom predmetu osam Slovakinja romskog porijekla tvrdilo je kako nakon poroda carskim rezom više nisu mogle zatrudnjeti. Sumnjajući da su sterilizirane bez njihova znanja tijekom godine, tužile su dvije slovačke bolnice. Sud je utvrdio da su podnositeljicama zahtjeva, koje nisu mogle dobiti fotokopije medicinske evidencija prekršena prava zajamčena čl. 8. i 6. st. 1.

U predmetu GB and RB v Moldova, App no 16761/09 (ECtHR, 18 December 2012) u kojem je također nad podnositeljicom izvršena sterilizacija tijekom poroda, no ne s ciljem sterilizacije već zbog liječničkog nemara. Sud je utvrdio povredu prava iz čl. 8 . podnositeljice, prije svega jer su nacionalni sudovi dodijelili podnositeljici izrazito mali iznos naknade štete (607 eura). Slično je Sud utvrdio i u predmetu Csoma v Romania, App no 8759/05 (ECtHR,15 January 2013)gdje je tijekom zahvata prekida trudnoće zbog zdravstvenog stanja fetusa, došlo do komplikacija koje su u konačnici učinile podnositeljicu neplodnom. Sud je utvrdio povredu prava iz čl. 8. zbog neuključivanja podnositeljice u izbor medicinskih postupaka kao i zbog nedovoljnog obavještavanja o rizicima do kojih može doći prilikom zahvata. 
odlučio brisati zahtjev. Naime, iako su sve tri podnositeljice bile žrtve sterilizacije koja nije bila nužna kao i što je ista bila obavljena uz njihov neinformirani pristanak, zahtjev treće podnositeljice nije raspravljen budući da je ona umrla te je Sud smatrao da su pitanja vezana uz prava iz čl. 3., 8., 12. i 14. Konvencije usko povezana s osobom prvobitne podnositeljice zahtjeva i da se ne mogu smatrati prenosivima. Stoga je Sud utvrdio da djeca treće podnositeljice zahtjeva nemaju pravo nastaviti postupak umjesto svoje majke. ${ }^{54}$

Možemo zaključiti kako u ovim predmetima Sud nije odstupio od svojih načelnih stavova o apsolutnosti čl. 3. niti prešao dopuštene granice tumačenja Konvencije, već je utvrdio povredu čl. 3. Konvencije u predmetima u kojima se s podnositeljicama postupalo na ponižavajući način unutar zdravstvenog sustava.

\section{1. c) Djeca i maloljetnici}

Vezano uz nepružanje zdravstvene skrbi kao povrede čl. 3. u odnosu na djecu i maloljetnike, načelno je činjenično stanje predmeta vrlo slično onima iz potpoglavlja o reproduktivnim pravima. Prije svega treba spomenuti predmet P. i S. protiv Poljske ${ }^{55}$ gdje su podnositeljice zahtjeva bile djevojčica od 14 godina koja je ostala trudna nakon silovanja i njezina majka. U Poljskoj je pobačaj legalan ako je trudnoća rezultat silovanja, što je bio slučaj u ovom predmetu, međutim liječnici su ju pokušavali odgovoriti od pobačaja. U prvoj bolnici bila je prisiljena razgovarati sa svećenikom, a da uopće nije bila upitana želi li to. Nadalje, liječnik je prisilio njezinu majku da potpiše obrazac koji tvrdi da pobačaj može rezultirati smrću njezine kćeri, iako za takvo što ne postoje medicinski dokazi. Podaci o njezinu stanju izašli su u javnost te se djevojčica svakodnevno susretala s prijetećim porukama od strane protivnika pobačaja te je nakon izlaska iz bolnice zatražila zaštitu policije koja je odbijena. Umjesto pružanja zaštite, bila je uhićena i smještena u ustanovu za smještaj maloljetnika, dok se protiv njezine majke pokrenuo postupak za oduzimanje roditeljskih prava zbog podržavanja pobačaja. Vlasti su pokrenule kazneni postupak i protiv kćeri, iako je ona bila žrtva seksualnog napada. Djevojčica je naposljetku uspjela obaviti pobačaj u klinici udaljenoj 500 kilometara od svoga doma. Sud je, donoseći odluku o povredi prava iz čl. 3., izjavio da su se P.-ine teškoće povećale zbog nedostatka jasnog pravnog okvira, odugovlačenja medicinskog osoblja i također kao posljedice uznemiravanja. U odluci se dalje navodi da je „[Sud] posebno pogođen time što su vlasti pokrenule kazneni postupak zbog ilegalnih seksualnih odnosa protiv adolescentice koja se, prema tužiteljstvu i medicinskim izvješćima, trebala smatrati žrtvom seksualnog zlostavljanja. ${ }^{\text {"56 }}$ Konačno, Sud je utvrdio kako je prvoj podnositeljici, odnosno djevojčici, zbog navedenih razloga povrijeđeno pravo iz čl. $3 .{ }^{57}$

54 Suprotno tome, vidi odluku Suda u predmetu Paposhvili v Belgium (n46).

55 App No 57375/08 (ECtHR 30 October 2012).

56 Ibid 165.

57 U konkretnom predmetu, osim utvrđenja povrede prava iz čl. 3. podnositeljice, Sud je presudio sa šest glasova za i jednim protiv da je došlo do kršenja čl. 8. Konvencije u pogledu utvrđivanja pristupa zakonitom pobačaju u odnosu na obje podnositeljice zahtjeva; jednoglasno je utvrdio da je došlo do kršenja članka 8. Konvencije u pogledu otkrivanja osobnih podataka podnositeljica zahtjeva: jednoglasno je utvrdio da je došlo do povrede čl. 5., st. 1. Konvencije u odnosu na prvu podnositeljicu zahtjeva. 
Sljedeći značajan predmet je N. B. protiv Slovačke ${ }^{58}$ a koji se odnosi na prisilnu sterilizaciju osoba romske nacionalnosti, no s maloljetnicom kao podnositeljicom. U konkretnom predmetu podnositeljica zahtjeva prisilno je sterilizirana tijekom poroda carskim rezom svog drugog djeteta kada je imala 17 godina za koji je, s obzirom na njezinu dob, bio potreban informirani pristanak zakonskih skrbnika (roditelja) koji oni nisu dali, dok u izvještaju o puštanju iz bolnice nije uveden nikakav zapis o sterilizaciji. N. B. je o sterilizaciji saznala tek nekoliko mjeseci kasnije, nakon što su odvjetnici pregledali njezine medicinske kartone u bolnici. U svojoj je odluci Europski sud zaključio da je prisilna sterilizacija povrijedila fizički integritet podnositeljice zahtjeva te grubo nepoštovala njezino ljudsko dostojanstvo. Utvrđeno je kako je sterilizacija podnositeljice izvršena dok je bila u trudovima i natjerana da pristane na tako ozbiljan medicinski postupak dok su joj na kognitivne sposobnosti utjecali lijekovi. Nadalje, pogrešno je utvrđeno kako je navedeni postupak prijeko potreban za očuvanje njezina života. Sud je također utvrdio da Slovačka nije ispunila svoju pozitivnu obvezu prema čl. 8. da kroz svoj pravni sustav osigura prava zajamčena tim člankom, uspostavljanjem učinkovitih pravnih mjera zaštite reproduktivnog zdravlja, posebno žena romskog podrijetla kao ranjive skupine u društvu. ${ }^{59}$

U posljednjem predmetu koji ćemo spomenuti riječ je bila o predmetu u kojem Sud nije smatrao kako je povreda dosegnula minimalni stupanj okrutnosti da bi ušla u okvir čl. 3 . Konkretno, u predmetu M. A. K. i R. K. protiv Ujedinjene Kraljevine, ${ }^{60}$ 1997. i ponovno 1998. podnositelj zahtjeva M. A. K. odveo je kćer obiteljskom liječniku jer su on, supruga i učitelj plivanja njihove kćeri bili zabrinuti zbog neobjašnjivih modrica na nogama. Uslijedio je posjet pedijatru koji je uzeo uzorke krvi i slike djevojčice u odsutnosti roditelja i unatoč naznaci oca da bi bilo kakve pretrage trebalo raditi u majčinoj nazočnosti ili uz njezin izričiti pristanak. Pedijatar je nakon pregleda genitalija i nogu djevojčice zaključio da je seksualno zlostavljana i obavijestio socijalne radnike. Na kraju je utvrđeno da djevojčica nije zlostavljana već da boluje od rijetke kožne bolesti te je ubrzo otpuštena iz bolnice. Sud je, u svojoj ocjeni, zaključio kako nacionalno zakonodavstvo predviđa pristanak roditelja, da je otac dao jasan zahtjev da se ne obavljaju pretrage bez pristanka majke te da se testovi smiju provesti bez pristanka samo u slučaju hitnosti, dok u ovom slučaju ne postoje dokazi da je djevojčica bila u životnoj opasnosti ili trpjela bolove. Sud je u ovom slučaju našao povredu čl. 8. Konvencije.

Upravo zbog odluke Suda kako u posljednjem prikazanom predmetu nije došlo do povrede čl. 3., možemo zaključiti da, kao i u predmetima koji se odnose na reproduktivna prava, Sud nije svojim odlučivanjem proširio opseg prava zajamčenih čl. 3. na pitanja koja ulaze u okvir zdravstvene zaštite, već je povrede utvrđivao isključivo zbog teških oblika nečovječnog i ponižavajućeg postupanja u zdravstvenom sustava prema podnositeljicama.

58 App No 29518/10 (ECtHR 12 June 2012).

59 Podnositeljica se pozvala i na povredu postupovnog aspekta čl. 3. te na povrede čl. 14. i čl. 1. Pr. 12. no Sud nije utvrdio povrede navedenih članaka, odnosno postupovnog aspekta čl. 3. dok povrede čl. 14. i čl. 1. Pr. 12. nije ni ispitivao. Autoricama ostaje nejasno zašto Sud nije ispitivao povredu čl. 14. zajedno s čl. 8. budući da je iz činjenica slučaja jasno, a i sam Sud je potvrdio, kako su pripadnice romske manjine posebno pogođena skupina u predmetima prisilne sterilizacije. 


\section{ZAKLJUČAK}

Koliko je važno pružanje zdravstvene zaštite, može se zaključiti iz mnogobrojnih dokumenata koji osiguravaju pravo na takvu zaštitu. Međutim, Konvencija nije jedan od tih dokumenata, već je pravo na zdravstvenu zaštitu, u okviru Vijeća Europe, zajamčeno Europskom socijalnom poveljom. Unatoč tome, Sud je razvio relativno bogatu sudsku praksu, prije svega u predmetima koji se odnose na zdravstvenu zaštitu osoba lišenih slobode, no određene presude mogu se naći u odnosu na pružanje zdravstvene skrbi osobama koje nisu lišene slobode, i to u kontekstu čl. 2., 3. i 8. Konvencije. Pacijenti se često susreću s problemom diskriminatornog postupanja od strane medicinskih djelatnika, kao i s problemom nepoštovanja njihove privatnosti te tjelesnog i moralnog integriteta.

U ovom radu detaljnije je analiziran čl. 3. Konvencije s aspekta pružanja zdravstvene skrbi izvan konteksta zadržavanja. Iako navedeni članak sadrži samo jednu rečenicu kojom se zabranjuje mučenje, nečovječno i ponižavajuće postupanje ili kažnjavanje, zahvaljujući evolutivnom tumačenju Europskog suda, široki spektar povreda može potpasti pod polje primjene čl. 3., pa tako i propust države da omogući pružanje (adekvatne) zdravstvene skrbi ili čak deportacija podnositelja u zemlju u kojoj mu neće biti pružena adekvatna zdravstvena skrb. Nepružanje zdravstvene skrbi ne predstavlja problem samo unutar konteksta zadržavanja, već i izvan njega te je praksa Suda u navedenim predmetima bila predmet izučavanja ovog rada.

S obzirom na prikazanu praksu, možemo zaključiti kako Sud nije izašao iz okvira dopuštenog tumačenja Konvencije te je, vezano uz praksu vezanu uz čl. 3. i prava na zdravstvenu skrb izvan konteksta zadržavanja, razvio relativno stabilnu praksu utvrđivanja povrede. Stoga je u predmetima koji se tiču reproduktivnih prava, Sud jasno utvrdio kako će prisilni i neinformirani postupci sterilizacije kao i onemogućavanje pobačaja pacijenticama koje udovoljavaju zakonskim pretpostavkama za isti, kao i ponižavajuće postupanje prema njima, predstavljati povredu čl. 3 .

Nadalje, predmeti koji se odnose na pružanje zdravstvene skrbi maloljetnicima i djeci relativno su kompatibilni s onima koji se odnose na reproduktivna prava, s tim da je riječ o ranjivoj skupini gdje je Sud još osjetljiviji, odnosno lakše utvrđuje kako je udovoljeno minimalnom stupnju okrutnosti da bi predmet spadao pod opseg čl. 3. Stoga je u predmetima neinformirane sterilizacije maloljetnice romske nacionalnosti kao i onemogućavanja, odnosno otežavanja obavljanja prekida trudnoće silovanoj maloljetnici, jednoglasno utvrdio povredu zabrane nečovječnog i ponižavajućeg postupanja.

Konačno, najspornijima možemo smatrati predmete koji su prvi prikazani u ovom radu, gdje postoji najviše prijepora oko odluka Suda, a koji se odnose na deportaciju podnositelja u zemlje gdje se suočavaju s ozbiljnim rizikom od ozbiljnog pogoršanja već narušenog zdravlja. Iako je Sud u ključnim predmetima, D. protiv Ujedinjene Kraljevine i N. protiv Ujedinjene Kraljevine, naizgled postavio standarde odlučivanja u takvim predmetima, iz postojeće prakse evidentno je kako navedeni standardni nisu jasno određeni već podložni odlučivanju od predmeta do predmeta. Navedeno case by case odlučivanje relativno je uobičajena praksa Suda, no ne u predmetima u kojima se odlučuje o povredi apsolutno nederogabilnih prava kao što su ona zajamčena čl. 3. već u predmetima u kojima se odlučuje uzimajući u obzir polje slobodne procjene država, dakle kod odlučivanja o povredi kvalificiranih konvencijskih prava. Međutim, 
brojna praksa Suda kao i suočavanje s relativno novim izazovima pri odlučivanju, donose sa sobom i ovakve prijepore. Ostaje vidjeti hoće li Sud, pri daljnjem odlučivanju ostati relativno nejasan u primjeni standarda „blizu smrti“ i drugim „iznimno opasnim okolnostima“, kao što se čini u ovom trenutku.

\section{BIBLIOGRAFIJA}

1. Baderin MA and McCorquodale R (ed), Economic, Social and Cultural Rights in Action (OUP 2007)

2. Brems E, 'Indirect Protection of Social Rights by the European Court of Human Rights' in Barak-Erez D and Gross AM (ed), Exploring Social Rights Between Theory and Practice (Hart Publishing 2007)

3. Churchill R and Khaliq U, 'The Collective Complaints System of the European Social Charter: An Effective Mechanism for Ensuring Compliance with Economic and Social Rights?' (2004) 15(3) European Journal of International Law 417

4. Dzehtsiarou K, 'What is Law for the European Court of Human Rights?' (2017) 49(1) Georgetown Journal of International Law 89

5. Dzehtsiarou K, European consensus and the legitimacy of the European court of human rights (CUP 2015)

6. Eide A, 'Economic, Social and Cultural Rights as Human Rights' in Eide A and others (eds) Economic, Social and Cultural Rights: A textbook (Kluwer Law International 2001)

7. Eide A, Report on the Right to Adequate Food as a Human Right, E/CN.4/Sub.2/1987/23 (UN 1987)

8. Fredman S, Human Rights Transformed: Positive Rights and Positive Duties (OUP 2008)

9. Gomien D, Europska konvencija o ljudskim pravima: priručnik (Naklada 2007)

10. Greer S, The European Convention on Human Rights: Achievements, Problems and Prospects (CUP 2006)

11. Harris D, The European Social Charter, The Protection of Economic and Social Rights in Europe (2nd edn, Brill - Nijhoff 2011)

12. Koch IE, 'The Justiciability of Indivisible Rights' (2003) 72 Nordic Journal of International Law 3

13. Koch IE, Human Rights As Indivisible Rights: The Protection of Socio-Economic Demands Under the European Convention On Human Rights (Brill - Nijhoff 2009)

14. Lester, Lord of Herne Hill 'Universality versus Subsidiarity: A Reply' (1998) 1 European Human Rights Law Review 73

15. Letsas G, A Theory of Interpretation of the European Convention on Human Rights (OUP 2009)

16. Letsas G, 'The ECHR as a Living Instrument: its Meaning and Legitimacy' in Føllesdal A, Peters B and Ulfstein G (eds), Constituting Europe: The European Court of Human Rights in a National, European and Global Context (Studies on Human Rights Conventions, CUP 2013)

17. Marochini M, 'Council of Europe and the Right to Healthcare - Is the European Convention on Human Rights Appropriate Instrument for Protecting the Right to Healthcare? ' (2013) 34(2) Zbornik Pravnog fakulteta Sveučilišta u Rijeci 729

18. Marochini M, 'The interpretation of the European Convention on Human Rights' (2014) 51(1) Zbornik radova Pravnog fakulteta u Splitu 63

19. Marochini M, Socio-Economic Dimension of the European Convention on Human Rights (Pravni fakultet u Rijeci 2013) 
20. Marochini M, 'The Ill-treatment of Prisoners in Europe: A Disease Diagnosed but not Cured?' (2009) 30(2) Zbornik Pravnog fakulteta Sveučilišta u Rijeci 1108

21. Marochini Zrinski M, 'Primjena Europske socijalne povelje s posebnim naglaskom na Republiku Hrvatsku' (2014) 14(11) Hrvatska pravna revija 42

22. McRae D, 'Approaches to the Interpretation of Treaties: The European Court of Human Rights and the WTO Appellate Body' in Breintenmoser S and others (eds), Human Rights, Democracy and the Rule of Law: Liber amicorum Luzius Wildhaber (Nomos 2007)

23. Mowbray A, The Development of Positive Obligations under the European Convention on Human Rights by the European Court of Human Rights (Hart Publishing 2004)

24. Omejec J, Konvencija za zaštitu ljudskih prava i temeljnih sloboda: Strasbourški acquis (Novi informator 2014)

25. Rainey B, Wicks E and Ovey C, The European Convention on Human Rights (5th edn, OUP 2017)

26. Reidy A, The Prohibition of Torture: a guide to the Implementation of Article 3 of the European Convention on Human Rights (Council of Europe 2003) <www.refworld.org/docid/49f1829b2.html> pristupljeno 13. srpnja 2021.

27. Senden HCK, 'Interpretation of fundamental rights in a multilevel legal system: an analysis of the European Court of Human Rights and the Court of Justice of the European Union' (Doctoral Thesis, Leiden University 2011)

28. Shue H, Basic Rights, Subsistence, Affluence and U.S. Foreign Policy (Princeton University Press 1980)

29. Van Boven T, 'Categories of Rights' in Moeckli D (ed), International Human Rights Law (OUP 2010)

30. Vasek K, 'A 30-Year Struggle: The Sustained Efforts to give Force of Law to the UDHR' (1977) 30(11) UNESCO Courier 29

31. Wisniewski A, The European Court of Human Rights: Between Judicial Activism and Passivism (Gdansk University Press 2016)

32. Yamin AE, 'The Future in the Mirror: Incorporating Strategies for the Defense and Promotion of Economic, Social and Cultural Rights into the Mainstream Human Rights Agenda' (2007) 27(4) Human Rights Quarterly 1200

\section{PROPISI I DOKUMENTI}

1. Bečka konvencija o pravu međunarodnih ugovora (NN-MU 16/1993) (HR)

2. Povelja Europske unije o temeljnim pravima (2012) OJ C326/391

3. Constitution of the World Health Organization, 2006 <www.who.int/governance/eb/who_constitution_en.pdf> pristupljeno 13. srpnja 2021.

4. (Europska) Konvencija za zaštitu ljudskih prava i temeljnih sloboda: pročišćeni tekst (NN-MU 18/1997, 6/1999, 14/2002, 13/2003, 9/2005, 1/2006, 2/2010) (HR)

5. European Social Charter (Council of Europe, 2021) <www.coe.int/en/web/european-social-charter/ home> pristupljeno 13. srpnja 2021.

6. Odluka o objavi Opće deklaracije o ljudskim pravima (NN-MU 12/2009) (HR)

7. United Nations, Final Act of the International Conference on Human Rights, Teheran, 22 April to 13 May 1968, A/CONF.32/41

8. United Nations, Vienna Declaration and Programme of Action, World Conference on Human Rights, Vienna, 14-25 June 1993, A/CONF.157/23 
9. Ustav Republike Hrvatske: pročišćeni tekst (NN 56/1990, 135/1997, 8/1998, 113/2000, 124/2000, 28/2001, 41/2001, 55/2001, 76/2010, 85/2010, 5/2014) (HR)

10. Zakon o potvrđivanju Europske socijalne povelje, Dodatnog protokola Europskoj socijalnoj povelji, Protokola o izmjenama Europske socijalne povelje i Dodatnog protokola Europskoj socijalnoj povelji kojim se uspostavlja sustav kolektivnih žalbi (NN-MU 15/2002) (HR)

\section{PRESUDE I DRUGE ODLUKE}

1. Calvelli and Ciglio v Italy, App no 32967/96 (ECtHR, 17 January 2002)

2. Csoma v Romania, App no 8759/05 (ECtHR,15 January 2013)

3. $\quad D v$ The United Kingdom (1997) 24 EHRR 423

4. Durisotto v Italy, App no 62804/13 (ECtHR, 6 May 2014)

5. Erikson v Italy (2000) 29 EHRR CD152

6. Eryiğit $v$ Turkey, App no 18356/11 (ECtHR, 10 April 2018)

7. Gard and others $v$ The United Kingdom, App no 39793/17 (ECtHR, 27 June 2017)

8. GB and RB v Moldova, App no 16761/09 (ECtHR, 18 December 2012)

9. Georgel and Georgeta Stoicescu v Romania, App no 9718/03 (ECtHR, 26 July 2011)

10. Hristozov and others v Bulgaria, App no 47039/11 and 358/12 (ECtHR, 13 November 2012)

11. İbrahim Keskin v Turkey, App no 10491/12 (ECtHR, 27 March 2018)

12. IG, MK and RH v Slovakia, App no 15966/04 (ECtHR, 13 November 2012)

13. Ireland $v$ The United Kingdom (1979-80) 2 EHRR 25

14. Jurica v Croatia, App no 30376/13 (ECtHR, 2 May 2017)

15. KH and others $v$ Slovakia (2009) 49 EHRR 857

16. LCB v The United Kingdom (1999) 27 EHRR 212

17. MAK and RKv The United Kingdom (2010) 51 EHRR 396

18. Mehmet Sentürk and Bekir Sentürkv Turkey (2013) 60 EHRR 4

19. $N v$ The United Kingdom (2008) 47 EHRR 39

20. NB v Slovakia, App no 29518/10 (ECtHR, 12 June 2012)

21. Nitecki $v$ Poland, App no 65653/01 (ECtHR, 21 March 2002)

22. $P$ and $S v$ Poland, App no 57375/08 (ECtHR, 30 October 2012)

23. Paposhvili v Belgium, App no 41738/10 (ECtHR, 13 December 2016)

24. Passannante v Italy, App no 32647/96 (ECtHR, 1 July 1998)

25. Pentiacova and others v Moldova (2005) 40 EHRR SE23

26. Roche $v$ The United Kingdom (2006) 42 EHRR 30

27. $R R v$ Poland, App no 27617/04 (ECtHR, 26 May 2011)

28. Savran v Denmark, App no 57467/15 (ECtHR, 1 October 2019)

29. Selmouni $v$ France (2000) 29 EHRR 403

30. Sentges $v$ Netherlands, App no 27677/02 (ECtHR, 8 July 2003)

31. SJv Belgium, App no 70055/10 (ECtHR, 19 March 2015) 
32. Šilih v Slovenia (2009) 49 EHRR 37

33. Vasileva v Bulgaria (2003) 40 EHHR 681

34. VC v Slovakia, App no 18968/07 (ECtHR, 8 November 2011)

35. Yoh-Ekale Mwanje v Belgium (2011) 56 EHRR 1140

\section{MREŽNI IZVORI}

1. About the CPT (Council of Europe, 2021) <www.coe.int/en/web/cpt/about-the-cpt> pristupljeno 13. srpnja 2021.

2. Ganty S, 'SJ v Belgium: missed opportunity to fairly protect seriously ill migrants facing expulsion' (Strasbourg Observers, 30 April 2015) <https://strasbourgobservers.com/2015/04/30/s-j-v-belgium-missed-opportunity-to-fairly-protect-seriously-ill-migrants-facing-expulsion $>$ pristupljeno 13. srpnja 2021.

3. Prisoner's helath related rights: factsheet (European Court of Human Rights, July 2020) <www.echr. coe.int/Documents/FS_Prisoners_health_ENG.pdf>pristupljeno 13. srpnja 2021.

4. Vodič kroz članak 2. Europske konvencije o ljudskim pravima: Pravo na život (Vijeće Europe, ažuriran 31. prosinca 2018.) <https://uredzastupnika.gov.hr/UserDocsImages//dokumenti/Edukacija// Vodi\%C4\%8D\%20kroz\%20\%C4\%8Dlanak\%202.\%20Konvencije.pdf> pristupljeno 13. srpnja 2021.

5. Vodič kroz članak 8. Europske konvencije o ljudskim pravima: Pravo na poštovanje privatnog i obiteljskog života, doma i dopisivanja (Vijeće Europe, ažuriran 31. kolovoza 2018) <https://uredzastupnika.gov.hr/UserDocsImages//dokumenti/Edukacija//Vodi\%C4\%8D\%20kroz\%20\%C4\%8Dl\%20 8.\%20Konvencije.pdf> pristupljeno 6. svibnja 2020. 


\section{FAILURE TO PROVIDE HEALTH CARE AS A VIOLATION OF ARTICLE 3 OF THE EUROPEAN CONVENTION WITH SPECIAL REFERENCE TO THE COURT'S CASE-LAW OUTSIDE THE CONTEXT OF DETENTION}

\section{Summary}

The European Convention on Human Rights, as a main Council of Europe instrument for the protection of civil and political rights, does not guarantee the right to health care. However, the European Court of Human Rights broadly interprets Convention rights, and within the context of Articles 2, 3 and 8 of the Convention it gave certain indications that it might start dealing with the issue of health care. Without going into details of all the mentioned articles, this paper will analyse cases where the Court dealt with the issue of violation of Article 3 due to non-provision of health care outside the context of detention. Namely, within the context of detention, there is a clear obligation for states to provide health care, and the Court often relies on the reports of the Committee for the Prevention of Torture and Inhuman or Degrading Treatment or Punishment. What we consider important to point out is the Court's caselaw on providing health care outside the context of detention, given the social character of the right to health care, which goes beyond the civil and political character of the Convention.

Keywords: $\quad$ European Convention for the Protection of Human Rights and Fundamental Freedoms, Article 3, health care outside the context of detention 